\title{
Effect of Lactobacillus plantarum DAD-13 and Fructo-oligosaccharides on Short-Chain Fatty Acid Profile and Nutritional Status in Indonesian Stunting Children
}

\author{
Delima Gunawan ${ }^{1}$, Muhammad Juffrie ${ }^{2}$, Siti Helmyati ${ }^{3}$, Endang S Rahayu ${ }^{4,5 *}$ (i) \\ ${ }^{1}$ Doctoral Program in Medicine, Faculty of Medicine, Public Health and Nursing, Universitas Gadjah Mada, Yogyakarta, Indonesia; \\ ${ }^{2}$ Departement of Pediatrics, Faculty of Medicine, Public Health and Nursing, Universitas Gadjah Mada, Yogyakarta, Indonesia; \\ ${ }^{3}$ Department of Health Nutrition, Faculty of Medicine, Public Health and Nursing, Universitas Gadjah Mada, Yogyakarta, \\ Indonesia; ${ }^{4}$ Department of Food and Agricultural Product Technology, Faculty of Agricultural Technology, Universitas Gadjah \\ Mada, Yogyakarta, Indonesia; ${ }^{5}$ Center for Food and Nutrition Studies, Universitas Gadjah Mada, Yogyakarta, Indonesia
}

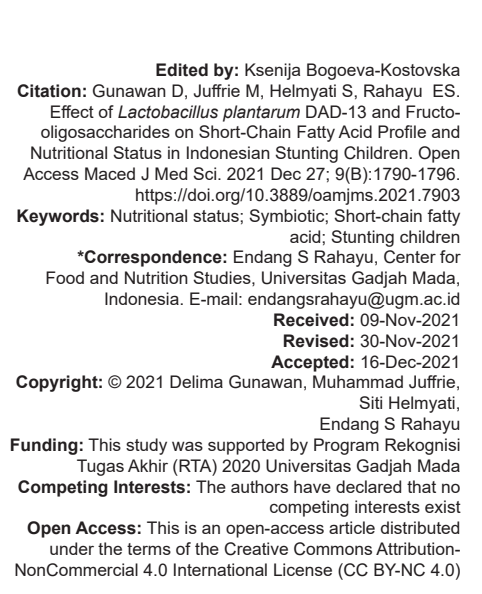

\section{Abstract}

BACKGROUND: Chronic gut inflammation is a generalized disturbance of small intestine structure and function is likely to play a large role in the incidence of stunting. It will be disturbances the absorption of nutrients, therefore, it can indirectly reduce on nutritional status.

AIM: The aim of this study is to examine the effect of Lactobacillus plantarum DAD-13 and fructooligosaccharide on short-chain fatty acid (SCFA) profile and nutritional status in Indonesian stunting children.

METHODS: The study design was used double-blind randomized placebo-controlled trial, 39 stunting children under five received daily oral supplementations of $L$. plantarum DAD-13 $1 \times 1010 \mathrm{cfu}$ and fructooligosaccharide $700 \mathrm{mg}$ (symbiotic group) or placebo group for 90 days. SCFA profile was analyzed using gas chromatography and nutritional status was assessed by WAZ, HAZ, and WHZ.

RESULTS: The result shows in symbiotic and control group, the mean age was $26 \pm 8.34$ and $29 \pm 5.78$, and the mean weight was $8.5 \pm 0.94 \mathrm{~kg}$ and $9.0 \pm 0.82 \mathrm{~kg}$, while the mean height was $78.96 \pm 5.4 \mathrm{~cm}$ and $80.9 \pm 4.55 \mathrm{~cm}$ respectively. Concentrations of acetate, propionate, and butyrate in the symbiotic group after consumption were $17.10 \pm 2.97,7.70 \pm 2.05$, and $7.47 \pm 1.76$ while in placebo group $12.44 \pm 3.61,5.20 \pm 1.66$, and $6.12 \pm 1.16$ respectively. There was a significant difference in the mean SCFA concentration between the symbiotic and placebo groups $(p<0.05)$, where the SCFA concentration in the symbiotic group was significantly higher than the placebo group. Nutritional status (WAZ, HAZ, and WHZ) was observed significantly in symbiotic group $(p<0.05)$, only on WHZ has cutoff point >-2SD after the intervention, while WAZ and $H A Z<-2 S D$.

CONCLUSIONS: L. plantarum DAD-13 and fructooligosaccharide 90 days supplementation have increase acetate butyrate, and propionate that are important fuels for intestinal epithelial cells that can play an important role in the maintenance of health.

\section{Introduction}

Stunting is one of the problems on children under 5 years in Indonesia and other developing countries [1]. Stunting is defined by a low height-forage $z$ (HAZ) score (<2SD) according to the World Health Organization Child Growth Standards. Stunting is associated with insufficient nutritional intake to support the rapid growth and development of infants and children, followed by recurrent infectious diseases that occur early in life [2], [3]. Based on basic health research in 2018, the incidence of stunting in Indonesia is $30.8 \%$. This number is still very far from the target set by the WHO, which is $20 \%$ [1]. Therefore, this is a problem that must be given more attention as stunting (linear growth failure) resulted in irreversible impact [4].

Recently, evidence suggested that a chronic syndrome which causes inflammation of on small intestine, known as pediatric environmental enteropathy (PEE), is likely to play a large role in the incidence of stunting. Stunting child gut has an abundance of enteric pathogens, namely, Enterobacteriaceae and other pathogenic bacteria. Consequently, the beneficial microbes level will be low, which are known to cause inflammation on gut [5]. There will be a low level of shortchain fatty acid (SCFA) especially acetate, propionate, and butyrate and elevation in stools $\mathrm{pH}$, if there is an imbalance or loss of bacterial diversity in the human digestive tract or dysbiosis. If this happens, there will be disturbance the absorption of nutrients, both macro and micronutrients; thus, it is expected to indirectly decrease nutritional status (WAZ, HAZ, or WHZ) on children with stunting [6]. Stunted children with dysbiosis cannot recover only by a nutritious diet alone, but they also need probiotic, prebiotic, and symbiotic to modulate the microbiota composition especially microbiota containing potentially beneficial for human health [7], [8], [9], [10]. 
Probiotics are live microorganisms that can provide good or health effects on other organisms/their hosts. Prebiotics are non-viable food components, with a beneficial effect on the host and are associated with microbiota modulation. Aside from its ability to enhance probiotic bacterial species, prebiotic shown to have an effect on improving physiological health [11]. Symbiotic is products that contain probiotic and prebiotic agents. The combination is supposed to enhance the survival of the probiotic bacteria through the upper gastrointestinal tract, improve implantation of prebiotic in colon, and stimulate the growth and/or activities of both the exogenously provided probiotic strain(s). The advantage of combining probiotic and prebiotic mainly comes from their abilities to increase the numbers of beneficial organism in colon, reduce the numbers of potentially pathogenic microorganisms, and stimulate SCFA production [12].

SCFA derived from bacteria-dependent hydrolysis of plant materials, such as celluloses, fiber, starches, and sugars [13], [14]. However, when plant materials supply decreases, some bacterial species can switch to amino acid and protein fermentation as an alternative energy source, which also contributing to SCFA. SCFAs are important fuels for intestinal epithelial cells (IECs) and to regulate IECs function through different mechanisms. The example of IEC function is the modulation of proliferation and cell metabolism, differentiation which influences gut motility and strengthens intestinal barrier functions and also plays a role in weight regulation [14], [15]. A healthy gut microbiota gives an important role to human metabolism by contributing enzymes that are not encoded by the human genome, for example, the breakdown of polysaccharides, polyphenols, and synthesis of vitamins, which are essential for human health [10], [16], [17]. It performs various protective, structural, and metabolism bowel function; especially the production of SCFAs. SCFA has three predominant forms of fatty acids, namely, acetate, propionate, and butyrate; each has a beneficial role for human health, such as improving the gut profile of the microbiota, nutrient intake, and improving nutritional status [14]. SCFAs act as source of nutrition and proliferation for IECs, development mucosal immune system, production of certain vitamins, promote mineral absorption, affect metabolism rate, and appetite, induction of host genes for nutrition absorption: All of which are essential for optimal nutrition absorption [18].

\section{Methods}

\section{Study design}

A randomized, double-blind, and placebocontrolled study was performed using symbiotic powder and skim milk (placebo). The clinical study period lasted 90 days from January to April 2020 at Rumah Pemulihan Gizi in Yogyakarta, Indonesia. Children under five with stunting were recruited in this study. The sample determination of stunting children under five was carried out by anthropometric screening for height-for-age (HAZ). Children with $H A Z<-2$ SD were chosen as research subjects. The sample size was calculated using hypothesis testing for differences in two proportions between two independence groups. The minimal number of subjects calculated, with $95 \%$ confidence interval, power of $80 \%-10 \%$ drop out into account. Subjects were randomly divided into two groups: 19 participants in symbiotic group and 20 participants in placebo group. The inclusion criteria are children aged 12-59 months with stunting and did not take probiotics a month before the study took place. During the study period, symbiotic powder group consumed $1 \mathrm{~g}$ of symbiotic powder once a day, while placebo group consumed $1 \mathrm{~g}$ of skim milk each day.

\section{Research products}

The study product was a symbiotic powder containing the indigenous probiotic strain of Lactobacillus plantarum DAD-13 $1 \times 10^{10} \mathrm{CFU}$ and $700 \mathrm{mg}$ of fructooligosaccharides (FOS). The symbiotic powder was consumed $1 \mathrm{~g} /$ day. The indigenous probiotic strain was deposited in ampoules at the Food and Nutrition Culture Collection (FNCC), Center for Food and Nutrition Studies, Universitas Gadjah Mada while the FOS was obtained from PT Beneo $\mathrm{GmbH}$. The placebo group consumed a commercial skim milk as much as $1 \mathrm{~g} / \mathrm{day}$.

\section{Fecal sample collection}

Subjects were given a fecal kit box as a place to store fecal samples a day before collection day. The fecal kit box containing sterile fecal bottle, trail paper, rubber gloves, masks, and ice gel was provided by the laboratory. Ice gel contained in the fecal kit box was previously frozen before used. The ice gel serves to keep the fecal sample cold $\left(<10^{\circ} \mathrm{C}\right)$ and it was transferred to the laboratory within $1 \mathrm{~h}$ [13].

\section{SCFA and stool $\mathrm{pH}$ analysis}

SCFA compounds were measured using the method from Salazar et al. (2014) [19]. Analysis of SCFA compounds using gas chromatography (GC) tools (Shidmadzu, GC series 2010 plus) with injector specifications of $240^{\circ} \mathrm{C}$, RTX-Wax column temperature and column length $145^{\circ} \mathrm{C}$ and $30 \mathrm{~m}$, diameter 0.25 , column flow 0.80 min using a helium carrier gas and using a flame ionization detector (FID) at $240^{\circ} \mathrm{C}$. A total of $0.2 \mathrm{~g}$ of fecal samples added with $1 \mathrm{ml}$ distilled water, vortex, sonification for $20 \mathrm{~min}$, and then centrifuged at $13,000 \mathrm{rpm}$ for $5 \mathrm{~min}$ at $4^{\circ} \mathrm{C}$. After that, supernatant 
was transferred and centrifuged again at 13,000 rpm for $5 \mathrm{~min}$ at $4^{\circ} \mathrm{C}$. Then, $1 \mathrm{ml}$ of supernatant was collected and ready to be analyzed with GC equipped with an FID detector and capillary column. Stool $\mathrm{pH}$ was analyzed using a $\mathrm{pH}$ meter ( $\mathrm{pH}$ Spear Eutech). After calibration using buffer, the probe was directly taking into the stool sample and kept until a stable measured value.

\section{Nutritional status}

Nutritional status of the study participants was assessed by three anthropometric indices that are generally used as measurement for children's nutritional status: Length-for-height for age z-score (HAZ), weight-for-age z-score (WAZ), and weight-for-height z-score (WHZ) [17]. Weight and height were measured monthly. A cutoff of $<-2 S D$ was used to distinguish normal children from those stunted (HAZ <-2 SD) or underweight (WAZ $<-2 S D)$ or wasted $(\mathrm{WHZ} \leq 2)$. Weight measurements were taken to the nearest of $0.1 \mathrm{~kg}$, using a standardized $20 \mathrm{~kg}$ infant digital scale and measurement of height was taken to nearest of $0.1 \mathrm{~cm}$, using measuring board for children under 2 years and microtomies for children over 2 years.

\section{Statistical analysis}

Statistical analyses were performed in $\mathrm{R}$ software (Version 2.15.3). Baseline characteristics of the study were compared by independent t-test analysis. Data are presented as mean \pm SD. Data were tested for normality using Shapiro-Wilk test. The comparisons between the groups were analyzed using t-test. Values with $p<0.05$ were considered statistically significant.

\section{Ethical Consideration}

The study was conducted in accordance with declaration of Helsinki. Parents or legal guardians were fully informed about the aim of the study and signed informed consent was obtained from at least one parent or legal guardians. Protocol was approved by the Ethical Committee, Faculty of Medicine, Public Health and Nursing, Universitas Gadjah Mada, Yogyakarta, Indonesia (approval date: November 25, 2019; reference number: KE/FK/1388/EC/2019).

\section{Results}

During this study period, 40 stunting children under 5 years old agreed to participate in this study, but during consumption period one of the subjects was dropped out as the subject refused to participate. There were no complains and/or adverse event by the intervention during and after intervention. The level of compliance was in a good category (mean $\geq 80 \%$ ) because the mothers of the subjects felt that since consumption period, their children's appetites have become better, so that the mothers almost never forget to give these products to their children. As a result, a total of 39 subject completed this clinical study (symbiotic group $=19$ and placebo $=20$ ). Figure 1 shows the flow diagram showing the subject's progression during this study period.

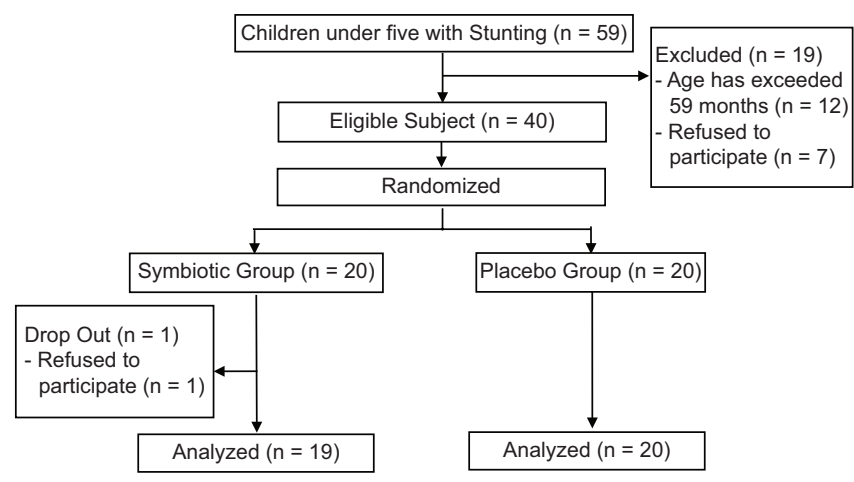

Figure 1. Recruitment of Study Subject: Flow chart

\section{Characteristic of subject}

There was no significant difference on both groups after baseline characteristic analysis. Therefore, it can be concluded that the subjects had the same characteristics at the baseline. Characteristics of research subjects including age, sex, and nutritional status of the subjects are shown in Table 1.

Table 1: Baseline characteristic of subject

\begin{tabular}{llll}
\hline Characteristics & $\begin{array}{l}\text { Symbiotic group } \\
(\mathrm{n}=19)\end{array}$ & $\begin{array}{l}\text { Placebo group } \\
(\mathrm{n}=20)\end{array}$ & $\mathrm{P}$ \\
\hline Sex & 12 & 13 & \\
$\quad$ Male & 7 & 7 & \\
$\quad$ Female & $26 \pm 8.34$ & $29 \pm 5.78$ & 0.194 \\
Age, month & $8.5 \pm 0.94$ & $9.0 \pm 0.82$ & 0.103 \\
Weight, kg & $78.96 \pm 5.4$ & $80.9 \pm 4.55$ & 0.241 \\
Height, cm & $-2.97 \pm 0.6$ & $-3.1 \pm 0.36$ & 0.561 \\
Weight for age (WAZ) & $-2.8 \pm 0.54$ & $-3.0 \pm 0.70$ & 0.384 \\
Height for age (HAZ) & $-2.15 \pm 0.6$ & $-2.0 \pm 0.63$ & 0.524 \\
Weight for height (WHZ) & &
\end{tabular}

\section{Short chain fatty acid and stool $\mathrm{pH}$}

The acetate, propionate, and butyrate levels found to be increase on fecal samples of both groups, but the most abundant was acetate. The results of SCFA profile are shown in Table 2. The acetate, propionate, and butyrate in symbiotic group after intervention were significantly increased. Conversely, in placebo group, significant different is only found in the concentration of acetate. The slightly significant difference between groups after consumption period on acetate, propionate, and butyrate levels can be seen when symbiotic and placebo group are compared. 
Table 2: The difference between and within groups on short-chain fatty acid

\begin{tabular}{|c|c|c|c|}
\hline \multirow[t]{2}{*}{ SCFA level } & \multicolumn{2}{|c|}{$\mathrm{mmol} / \mathrm{g}$ Feces $($ Mean \pm SD) } & \multirow[t]{2}{*}{$p$-value ${ }^{a}$} \\
\hline & Symbiotic group & Placebo group & \\
\hline \multicolumn{4}{|l|}{ Acetate } \\
\hline Before intervention & $10.02 \pm 3.44$ & $10.75 \pm 2.03$ & 0.427 \\
\hline After intervention & $17.10 \pm 6.88$ & $12.44 \pm 3.61$ & $0.000^{*}$ \\
\hline \multicolumn{4}{|l|}{ Propionate } \\
\hline Before intervention & $4.8 \pm 1.27$ & $4.79 \pm 0.71$ & 0.976 \\
\hline After intervention & $7.7 \pm 2.05$ & $5.20 \pm 1.66$ & $0.000^{*}$ \\
\hline \multicolumn{4}{|l|}{ Butyrate } \\
\hline Before intervention & $5.74 \pm 1.50$ & $5.97 \pm 0.92$ & 0.574 \\
\hline After intervention & $7.47 \pm 1.76$ & $6.12 \pm 1.16$ & $0.008^{*}$ \\
\hline
\end{tabular}

Figure 2 shows the significant difference in stool $\mathrm{pH}$ between groups after 90 days intervention with $p=0.000$. The symbiotic group had lower stool $\mathrm{pH}$ after the intervention, which was $6.31 \pm 0.16$, while the placebo group was $6.74 \pm 0.41$. The decrease in $\mathrm{pH}$ in the colon is due to the presence of organic acids produced by acid-producing bacteria (acetate, propionate, and butyrate) which stimulate motility in the colon.

\section{Nutritional status}

The comparison results from before and after consumption period in both groups are shown in Table 3. The average of z-score was on under nutrition category for WAZ and stunting category for $\operatorname{HAZ}(\leq-2 \mathrm{SD})$, while for HAZ the average of $z$-score was into normal category (>-2 SD). However, there was a significant increase for WAZ, HAZ, and WHZ on symbiotic group but not on placebo group.

Table 3: Differences comparison on nutritional status of subjects before and after intervention in both group

\begin{tabular}{|c|c|c|c|}
\hline $\begin{array}{l}\text { Nutritional } \\
\text { status }\end{array}$ & $\begin{array}{l}\text { Symbiotic group } \\
\text { Mean } \pm \text { SD }\end{array}$ & $\begin{array}{l}\text { Placebo group } \\
\text { Mean } \pm \text { SD }\end{array}$ & $p$-value ${ }^{a}$ \\
\hline \multicolumn{4}{|c|}{ Weight-for-age z-score (WAZ) } \\
\hline Before & $-2.96 \pm 0.62$ & $-3.06 \pm 0.36$ & 0.566 \\
\hline After & $-2.10 \pm 0.65$ & $-2.80 \pm 0.53$ & 0.001 \\
\hline \multicolumn{4}{|c|}{ Length/height-for-age z-score (HAZ) } \\
\hline Before & $-2.79 \pm 0.55$ & $-2.97 \pm 0.72$ & 0.409 \\
\hline After & $-2.12 \pm 0.48$ & $-2.83 \pm 0.75$ & 0.003 \\
\hline \multicolumn{4}{|c|}{ Weight-for-height Z-score (WHZ) } \\
\hline Before & $-2.14 \pm 0.70$ & $-2.00 \pm 0.64$ & 0.485 \\
\hline After & $-1.35 \pm 0.75$ & $-1.73 \pm 0.90$ & 0.104 \\
\hline
\end{tabular}

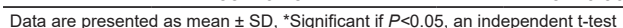

In Table 4, a detailed result of nutritional changes between symbiotic and placebo groups can be seen. When compared, a significant difference between groups after intervention on WAZ and HAZ is found. However, there was no significant difference on WHZ score between compared groups (Table 4).

\section{Discussion}

Stunting is a significant pediatric health problem worldwide that contributes to morbidity and mortality in children under 5 years of age [20]. A chronic syndrome causes inflammation of the small intestine, known as PEE in which an altered gut microbiota or dysbiosis and growth failure were found [21]. Dysbiosis refers to an altered gut microbiota composition that could lead to stunting even in the face of adequate food intake. The previous study shows that gut microbiota on stunting children is predominant in bacteria belonging to the inflammation taxa [6]. In this study, L. plantarum DAD-13 as a probiotic agent and FOS as a prebiotic agent were used. Previously, a study reported that 20 out of 20 healthy adolescent experienced an increase in the amount of $L$. plantarum after consuming the probiotic $L$. plantarum DAD-13 for 2 months. This shows that $L$. plantarum DAD-13 can live in the human gastrointestinal tract and has a beneficial impact on health. These results are in line with another research which states that $L$. plantarum DAD-13 is a strain that can survive in the digestive system, resistant to bile salt and gastric juice, and found in human feces who consume it [22]. FOS can increase Bifidobacterium that has an important role in human gut health. The decrease or loss of Bifidobacterium in the human gut indicates that they are not healthy [23]. Lactobacillus and Bifidobacterium, which can decrease inflammation, strengthen gut barrier function, inhibit pathogens, and mediate other beneficial effects under certain

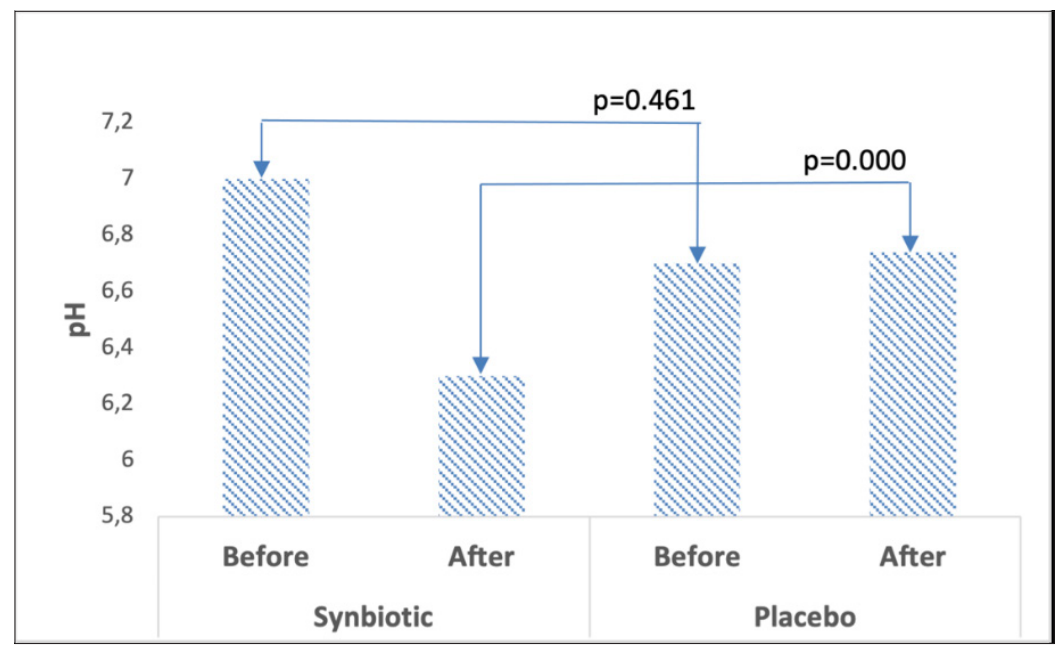

Figure 2: The different in stool $\mathrm{pH}$ between groups before and after intervention 
Table 4: Nutritional status (WAZ, HAZ, and WHZ)

\begin{tabular}{|c|c|c|c|c|c|c|c|c|}
\hline \multirow[t]{2}{*}{ Variable } & \multicolumn{4}{|c|}{ Symbiotic group } & \multicolumn{4}{|c|}{ Placebo Group } \\
\hline & $\begin{array}{l}\text { Increment } \\
\text { (subject) }\end{array}$ & $\begin{array}{l}\text { Average } \\
\text { (Min-max) }\end{array}$ & $\begin{array}{l}\text { Decrements } \\
\text { (subject) }\end{array}$ & Average $^{\star \star}($ Min-max $)$ & $\begin{array}{l}\text { Increment } \\
\text { (subject) }\end{array}$ & $\begin{array}{l}\text { Average } \\
\text { (Min-max) }\end{array}$ & $\begin{array}{l}\text { Decrements } \\
\text { (subject) }\end{array}$ & Average $^{\star \star}($ Min-max $)$ \\
\hline WAZ & $19(100 \%)$ & $0.87(0.34-1.81)$ & - & - & $13(65 \%)$ & $0.45(0.02-1.54)$ & $7(35 \%)$ & $-0.08(-0.13--0.01)$ \\
\hline HAZ & $18(94.7 \%)$ & $0.71(0.14-1.74)$ & $1(5.3 \%)$ & $-0.13(-0.13--0.13)$ & $16(80 \%)$ & $0.21(0.01-1.01)$ & $4(20 \%)$ & $-0.11(-0.2--0.07)$ \\
\hline
\end{tabular}

conditions, are deficient in stool from undernourished children.

Therefore, due to their favorable effect on the development of beneficial intestinal bacteria, the administration of prebiotics may participate in inhibiting the development of inflammation-inducing pathogens [24], [25]. Based on the previous study, it was revealed that overall the gut microbiota of stunted children was mostly consist of fluorogenic bacteria belonging to the Proteobacteria phylum, whereas those of children who were not stunted were mostly belong to probiotic species such as Bifidobacterium longum [2]. This shows that $L$. plantarum DAD-13 can reduce pathogens in the gut microbiota of specific group of subjects [26]. Fecal microbial communities from both undernourished cohorts, including increased proportions of pathogenic taxa within Proteobacteria, such as Enterobacteriaceae, Escherichia, Klebsiella, and Shigella, as by other studies [25], [2]. It should be noted that similar pattern of increased Proteobacteria proportions with decreased microbial diversity is found in inflammatory bowel disease patients. On the other hand, genera containing potentially beneficial organisms are depleted in the undernourished gut.

Symbiotic has both probiotic and prebiotic properties and was created to overcome possible difficultiesinthesurvivalofprobioticsinthegastrointestinal tract [27]. Therefore, an appropriate combination of both components in a single product should ensure a superior effect, compared to the activity of the probiotic or prebiotic alone, especially to cure the inflammation. The main aim of symbiotic is to stimulate the growth and activity of beneficial bacteria in the gastrointestinal tract, which confers a desirable health benefit to the host. Through mechanisms of antagonism (the production of antimicrobial substances) and competition for epithelial adhesion and nutrients, the intestinal microbiota acts as a barrier for pathogens. The gut microbiota plays an important role in metabolizing undigested protein and carbohydrates which results in SCFA, namely: Acetate, propionate, and butyrate which are subsequently used by the host as a source of energy [28]. As a result of the fermentation of carbohydrates, Bifidobacterium or Lactobacillus may produce some compounds inhibiting the development of gastrointestinal pathogens, as well as reducing the intestinal $\mathrm{pH}$ [29]. The $\mathrm{pH}$ reflecting the environment acidity due to microbial metabolites [30]. There was an increase in stool $\mathrm{pH}$ on stunting children. Based on the previous study, elevated fecal $\mathrm{pH}$ indicates a mark change in the gut microbiota, specifically a profound reduction on probiotic species [31]. Similar with the present study that reported after 90 days of consumption, L. plantarum DAD-13 and FOS resulted in the decrease a fecal $\mathrm{pH}$.

The Bifidobacterium genus showed tolerance behavior toward the change of SCFA level and lower fecal $\mathrm{pH}$. The low levels of propionate and butyrate were associated with inflammation [32]. Based on SCFA analysis, the level of acetate, propionate, and butyrate was significantly increase on symbiotic group after consuming symbiotic powder for 90 days. The synergy between probiotics and prebiotics can also reduce the $\mathrm{pH}$ of the intestinal lumen and stimulate cell proliferation to expand the surface of mineral absorption thereby increasing mineral bioavailability and leads to the increase of nutritional status [33]. The reported result is in line with this study where nutritional status (WAZ, HAZ, and WHZ) was significantly increased after consumption periods of 90 days. SCFAs are a subset of fatty acids produced by the gut microbiota during the fermentation of partially and non-digestible polysaccharides [34]. Acetate is a net fermentation product for most gut microbiota, whereas the production of butyrate and propionate are by specific bacterial species. A previous study investigated the effect of diet pattern, including the intake of fibers and iron, toward microbiota composition [35]. The study reported that diet pattern influences the microbiota composition, gut SCFA levels, gut motility, and strengthen the gut barrier functions. SCFAs are metabolite of microbial fermentation that derived from bacterialdependent hydrolysis of fiber. SCFAs are estimated to contribute $6 \%-10 \%$ of total energy requirements and the contribution is expected to be higher for humans consuming high-fiber diets and herbivorous species. To acquire energy metabolism efficiency, the communication between the gut and peripheral organs (pancreas, liver, adipose tissue, and brain) is crucial. Information about nutritional status in the gut is relayed by various signals, including gut derived hormones such as glucagon-like peptide-1 (GLP-1). Transient postprandial increases in GLP-1 influence metabolism such as promoting insulin secretion (incretin effect), inhibiting the gastric emptying, and increasing satiety. The GLP-1 secretion from enteroendocrine $L$ cells can be stimulated by consuming sugars, amino acids, and long-chain fatty acids. Dietary supplementation with fermentable fibers has been shown to increase GLP-1 levels in rodents and humans, where SCFAs can stimulate GLP-1 secretion in vitro. Thus, it has been suggested that by producing SCFA, gut microbiota can increase GLP-1 level. The absence of microbially produced SCFAs in germ-free colon results in 
significantly higher plasma GLP-1 levels in mice. As an adaptive reason in promoting nutrient absorption, this colonic-derived GLP-1 seems to slow down the transit time in small intestine [36].

\section{Conclusions}

The study demonstrated that 90 days of consuming symbiotic powder which consists of L. plantarum DAD-13 and FOS could contribute on the increase of SCFA (acetate, propionate, and butyrate) levels and lowering fecal $\mathrm{pH}$. These alterations can decrease the inflammation process and stimulate cell proliferation to expand the surface of mineral absorption thereby increasing mineral bioavailability and lead to the increase of nutritional status (WAZ, HAZ, and WHZ) on stunted children.

\section{Acknowledgments}

The authors are grateful to the FNCC, Center for Food and Nutrition Studies, Universitas Gadjah Mada for supplying $L$. plantarum DAD-13 for this study. The authors would like to give their appreciation and gratitude toward Rumah Pemulihan Gizi Yogyakarta where the study was carried out. In addition, the authors thank the participating parents and their children who volunteered in the study.

\section{References}

1. Huriah $\mathrm{T}$, Nurjannah $\mathrm{N}$. Risk factors of stunting in developing countries: A scoping review. Open Access Maced J Med Sci. 2020;8(F):155-60.

2. Dinh DM, Ramadass $B$, Kattula D, Sarkar R, Braunstein $P$, Tai $\mathrm{A}$, et al. Longitudinal analysis of the intestinal microbiota in persistently stunted young children in south India. PLoS One. 2016;11(5):e0155405. http://doi.org/10.1371/journal. pone.0155405

PMid:27228122

3. Dewey KG, Begum K. Long-term consequences of stunting in early life. Matern Child Nutr. 2011;7 Suppl 3:5-18. http://doi. org/10.1111/j.1740-8709.2011.00349.x

PMid:21929633

4. Prendergast AJ, Humphrey $\mathrm{JH}$. The stunting syndrome in developing countries. Paediatr Int Child Health. 2014;34(4):250-65. http://doi.org/10.1179/2046905514Y.0000000158 PMid:25310000

5. Gupta S, Mohammed M, Ghosh T, Kanungo S, Nair G, Mande SS. Metagenome of the gut of a malnourished child. Gut Pathog. 2011;3(1):7.

\section{PMid:21599906}

6. Monira S, Nakamura S, Gotoh K, Izutsu K, Watanabe H, Alam $\mathrm{NH}$, et al. Gut microbiota of healthy and malnourished children in Bangladesh. Front Microbiol. 2011;2:228. http://doi. org/10.3389/fmicb.2011.00228 PMid:22125551

7. Westerbeek EA, van Elburg RM, van den Berg A, van den Berg J, Twisk JW, Fetter WP, et al. Design of a randomised controlled trial on immune effects of acidic and neutral oligosaccharides in the nutrition of preterm infants: Carrot study. BMC Pediatr. 2008;8:46. http://doi.org/10.1186/1471-2431-8-46 PMid:18947426

8. Parfrey LW, Knight R. Spatial and temporal variability of the human microbiota. Clin Microbiol Infect. 2012;18 Suppl 4:8-11. http://doi.org/10.1111/j.1469-0691.2012.03861.x PMid:22647040

9. Stecher B. The roles of inflammation, nutrient availability and the commensal microbiota in enteric pathogen infection. Metab Bact Pathog. 2015;3(3):297-320. http://doi.org/10.1128/ microbiolspec

10. Kapel N, Thomas M, Corcos O, Mayeur C, Barbot-Trystram L, Bouhnik $\mathrm{Y}$, et al. Practical implementation of faecal transplantation. Clin Microbiol Infect. 2014;20(11):1098-105. http://doi.org/10.1111/1469-0691.12796 PMid:25273614

11. Artanti, A, Jennie BS, Surono, IS. Pengaruh Prebiotik Inulin dan Fruktooligosakarida (FOS) Terhadap Pertumbuhan Tiga Jenis Probiotik (The Effect of Inulin and Fructooligosaccharides (FOS) Towards the Growth Three Types of Probiotic). 2009. Bogor: Institut Pertanian Bogor; 2009.

12. Hawrelak JA. Prebiotics, synbiotics, and colonic foods Textbook of Natural Medicine. $5^{\text {th }}$ ed. Amsterdam, Netherlands: Elsevier Inc.; 2020. p. 797-808.e4. http://doi.org/10.1016/ B978-0-323-43044-9.00104-7

13. Marta BM, Tyas U, Nur CM, Jaka W, Sutriswati RE. Effects of consumption of probiotic powder containing Lactobacillus plantarum dad-13 on fecal bacterial population in school-age children in Indonesia. Int J Probiotics Prebiotics. 2019;14(1):1-8.

14. Martin-Gallausiaux $C$, Marinelli L, Blottière HM, Larraufie $P$ Lapaque N. SCFA: Mechanisms and functional importance in the gut. Proc Nutr Soc. 2021;80(1):37-49. http://doi.org/10.1017/ S0029665120006916

PMid:32238208

15. Surono IS, Widiyanti D, Kusumo PD, Venema K. Gut microbiota profile of Indonesian stunted children and children with normal nutritional status. PLoS One. 2021;16(1):e0245399. http://doi. org/10.1371/journal.pone.0245399 PMid:33497390

16. Aramico B, Sudargo T, Susilo J. Association between social economic aspect of the family, rearing pattern, eating pattern and stunting in elementary school children in Lut Tawar, Subditrict Central Aceh Regency. Indonesian J Nutr Diet. 2016;1(3):121.

17. Alou MT, Million M, Traore SI, Mouelhi D, Khelaifia S, Bachar D, et al. Gut bacteria missing in severe acute malnutrition, can we identify potential probiotics by culturomics? Front Microbiol. 2017;8:899. http://doi.org/10.3389/fmicb.2017.00899 PMid:28588566

18. Hijova E, Chmelarova A. Short chain fatty acids and colonic health. Bratisl Lek Listy. 2007;108(8):354-8.

19. Salazar N, Dewulf EM, Neyrinck AM, Bindels LB, Cani PD, Mahillon $\mathrm{J}$, et al. Inulin-type fructans modulate intestinal Bifidobacterium species populations and decrease fecal shortchain fatty acids in obese women. Clin Nutr. 2015;34(3):501-7. http://doi.org/10.1016/j.clnu.2014.06.001

PMid:24969566 
20. Gordon JI, Dewey KG, Mills DA, Medzhitov RM. The human gut microbiota and undernutrition. Sci Trans Med. 2012;4(137):137ps12. http://doi.org/10.1126/ scitransImed.3004347 PMid:22674549

21. Keusch GT, Denno DM, Black RE, Duggan C, Guerrant RL, Lavery JV, et al. Environmental enteric dysfunction: Pathogenesis, diagnosis, and clinical consequences. Clin Infect Dis. 2014;59 Suppl 4:S207-12. http://doi.org/10.1093/cid/ciu485 PMid:25305288

22. Dolly P, Anishaparvin A, Joseph GS, Anandharamakrishnan C Microencapsulation of Lactobacillus plantarum (mtcc 5422) by spray-freeze-drying method and evaluation of survival in simulated gastrointestinal conditions. J Microencapsul. 2011;28(6):568-74. http://doi.org/10.3109/02652048.2011.599435.

PMid:21827359

23. Mitsuoka T. Establishment of intestinal bacteriology. Biosci Microbiota Food Health. 2014;33(3):99-116. http://doi. org/10.12938/bmfh.33.99 PMid:25032084

24. De Preter V, Hamer HM, Windey K, Verbeke K. The impact of pre-and/or probiotics on human colonic metabolism: Does it affect human health? Mol Nutr Food Res. 2011;55(1):46-57. http://doi.org/10.1002/mnfr.201000451

PMid:21207512

25. Ghosh TS, Sen GS, Bhattacharya T, Yadav D, Barik A, Chowdhury A, et al. Gut microbiomes of Indian children of varying nutritional status. PLoS One. 2014;9(4):e95547. http:// doi.org/10.1371/journal.pone.0095547 PMid:24763225

26. Liwan SY, Utami T, Murdiati A, Triwitono P, Rahayu ES. Dietary patterns and effect of consumption of probiotic powder containing indigenous bacteria Lactobacillus plantarum Dad13 on Streptococcus, Enterococcus, Escherichia coli and Klebsiella pneumoniae in the gut of students at Junior High School Pangururan. Int Food Res J. 2020;27(5):790-7.

27. Pekmez CT, Dragsted LO, Brahe LK. Gut microbiota alterations and dietary modulation in childhood malnutrition-the role of short chain fatty acids. Clin Nutr. 2019;38(2):615-30. http://doi. org/10.1016/j.clnu.2018.02.014 PMid:29496274

28. Grajek W, OlejnikA, Sip A. Probiotics, prebiotics and antioxidants as functional foods. Acta Biochim Pol. 2005;52(3):665-71.

\section{PMid: 16086074}

29. Markowiak P, Ślizewska K. Effects of probiotics, prebiotics, and synbiotics on human health. Nutrients. 2017;9(9):1021. http:// doi.org/10.3390/nu9091021

PMid:28914794

30. Kamil RZ, Murdiati A, Juffrie M, Nakayama J, Rahayu ES. Gut microbiota and short-chain fatty acid profile between normal and moderate malnutrition children in Yogyakarta, Indonesia. Microorganisms. 2021;9(1):127. http://doi.org/10.3390/ microorganisms 9010127

PMid:33430510

31. Hossain MS, Das S, Gazi MA, Alam MA, Haque NM, Mahfuz M, et al. Association of faecal $\mathrm{pH}$ with childhood stunting: Results from a cross-sectional study. BMJ Paediatr Open. 2019;3(1):e000549. http://doi.org/10.1136/bmjpo-2019-000549 PMid:31646200

32. Ríos-Covián D, Ruas-Madiedo P, Margolles A, Gueimonde M, De Los Reyes-Gavilán CG, Salazar N. Intestinal short chain fatty acids and their link with diet and human health. Front Microbiol. 2016;7:185. http://doi.org/10.3389/fmicb.2016.00185 PMid:26925050

33. Ivanovska TP, Pavlova MJ, Mladenovska K, PetrushevskaTozi L. Probiotics, prebiotics, synbiotics in prevention and treatment of inflammatory bowel diseases. Maced Pharm Bull. 2014;60(2):3-19.

34. Tan J, McKenzie C, Potamitis M, Thorburn AN, Mackay CR, Macia L. The role of short-chain fatty acids in health and disease. In: Advances in Immunology. $1^{\text {st }}$ ed., Vol. 121. Amsterdam, Netherlands: Elsevier Inc.; 2014. p. 91-119. http:// doi.org/10.1016/B978-0-12-800100-4.00003-9

35. Müller M, Hermes GD, Emanuel EC, Holst JJ, Zoetendal EG, Smidt $\mathrm{H}$, et al. Effect of wheat bran derived prebiotic supplementation on gastrointestinal transit, gut microbiota, and metabolic health: A randomized controlled trial in healthy adults with a slow gut transit. Gut Microbes. 2020;12(1):1704141. http://doi.org/10.1080/19490976.2019.1704141 PMid:31983281

36. Wichmann A, Allahyar A, Greiner TU, Plovier H, Lundén $\mathrm{GÖ}$, Larsson $\mathrm{T}$, et al. Microbial modulation of energy availability in the colon regulates intestinal transit. Cell Host Microbe. 2013;14(5):582-90. http://doi.org/10.1016/j. chom.2013.09.012

PMid:24237703 